Published in the Journal of Bahá'í Studies Vol. 3, number 2 (1990)

(C) Association for Bahá'í TM Studies 1990

\title{
A Bahá'í Approach to the Claim of Exclusivity and Uniqueness in Christianity
}

\author{
Seena Fazel and Khazeh Fananapazir
}

\begin{abstract}
This article examines the nature of the claims of exclusivity in Christianity. Differing interpretations of certain scriptural passages have led to conflicts within the church and also between Christianity and other faiths. A Bahá'í approach is offered to reconcile these conflicts. The language of the Gospels is examined using insights gained from the Bahá'í writings and from contemporary Christian thinking. This perspective in the context of progressive revelation provides a rational framework on which similar issues in other religions can be approached.

Résumé

Cet article étudie la nature de la revendication de l'exelusivité au sein du Christianisme. Des interprétations divergentes de certains écrits saints ont entrainé des conflits au sein de l'église et également entre le Christianisme et d'autres religions. Une approche bahá'íe s'efforce de réconcilier ces conflits. L'Evangile est étudiée à l'aide d'explications tirées des écrits bahá'ís et aussi des idées chrétiennes contemporaines. Cette perspective. dans le contexte de la révélation progressive, nous fournit une structure rationnelle qui pourra également résoudre des questions semblables émanant d'autres religions.
\end{abstract}

\section{Resumen}

Esta disertación examina la índole de las afirmaciones de exclusividad en la cristianidad. Interpretaciones diferentes de ciertos pasajes bíblicos dieron lugar a conflictos dentro de la Iglesia y también entre la cristianidad y otras fes. Se presenta el parecer bahá'í con miras de reconciliar estos conflictos. Se examina el lenguaje del Evangelio usando profundizaciones logradas de los Escritos Bahá'í y también del pensamiento contemporáneo cristiano. Esta perspectiva, dentro del ambiente de la, revelación progresiva, provee un marco de referencia que permite acercamiento sobre temas parecidos en otras religiones.

Tnnumerable conflicts and wars have been influenced, inspired, and legitimized Ly religion. Simply looking from the Far East to the Middle East, this conclusion is amply confirmed in recent times:

... no one would fail to see in the Vietnam War there were religious factors at work (antagonism between Buddhist monks and the Catholic regime); that the conflict between India and Pakistan ... has to this day fed on the irreconcilable hostility between Hindus and Muslims, continually leading to new massacres (not to mention the blood shed by Indians and Sikhs); that the war between Iraq and Iran 
has roots in the centuries-old inner-Muslim rivalry and enmity between

Sunnites and Shiites. (Küng, Christianity 442)

One need only add the Arab-Israeli conflict and the fighting in Lebanon to show that the litany of crimes still perpetrated in the name of religion is bewildering. And it may be getting worse. A recent editorial of The Economist reviewing the revival of Islamic fundamentalism ends with the forecast: "Relax a bit about Iran. Brace yourself for the next explosion" ("Still Islam" 16). While it is not fair to blame religion for all these political conflicts or to reduce these struggles to religious ones, it is clear that religions have contributed significantly to recent strife. Hence, it is not surprising that Küng concludes his 1985 book by stating that "there will be no peace among the peoples of this world without peace among the world religions" (Christianity 443).

For Christianity, it would appear that the erroneous interpretations of scripture, particularly those leading to the dogmas of exclusivity, have played an important role. Historically, issues in the debate of exclusivity within the early Christian Church became "not so much the cause of conflict but its most convenient and hallowed battlefield” (Johnson, History 92). The dogma of the uniqueness and finality of Christianity has not only been a source of conflict and persecution within the Church but has also been used to justify triumphalism and crusades. Three particular examples are worthy of mention.

First, there is a connection between the Christian sense of superiority with its corollary of the inferiority and backwardness of the Judaism it "superseded," and the consequent almost subconscious anti-Semitism of the Christian world, continuing into the twentieth century. Christianity regarded Judaism not only as incomplete in failing to be fulfilled by God's final revelation but also as responsible for having deliberately rejected and killed Christ. As the feminist scholar Rosemary Ruether writes, "Thus Jews could be seen as having an especially demonic status as those who should have been able to recognize Christ on the basis of their spiritual predictions of the Messiah, and yet chose to reject and kill him. They are quasi-apostates and Christ-killers, not merely ignorant believers" (Dialogue 141).

A second consequence of the Christian sense of superiority was the European colonization and consequent exploitation of what we now call the Third World. The basic incentive was economic, but "the moral validation of the imperialist enterprise rested upon the conviction that it was a great civilising and uplifting mission, one of whose tasks was to draw the unfortunate heathen up into the higher, indeed highest, religion of Christianity" (Hick, Non-Absoluteness 19).

Finally, such claims of exclusivity are frequently at the root of a Christian's difficulty in investigating and respecting other religions. Indeed many of the books and pamphlets attacking Bahá'í thought repeatedly revert to exclusivist doctrines. For instance, one such work states, “According to the Bible, God's revelation through Jesus is not subject to replacement by any newer, higher, or more complete revelation ... Lordship is something Jesus does not share" (Boykin, Bahá'í 23, 30). Another such work starts a chapter with the heading, “Jesus Christ is the only Saviour for all eternity” (Beckwith, Bahá'í 26). A third concludes by 
asking: “As a Bahá'í have you read John's Gospel and evaluated the claims of Christ to be the 'way, the truth, and the life ...??” (McCormick, History 20).

It is important to bear in mind that there are differing, and frequently contradictory, attitudes towards the dogma of exclusivity among the various schools of Christian thought. The Christian groups that are most clearly exclusivist have been labelled evangelicals and fundamentalists. ${ }^{1}$ However, many Christians, including Catholics, believe that their religion is not the only way to salvation. ${ }^{2}$

In attempting to address the issue of religious conflict, an important prerequisite is a dispassionate examination of those scriptural passages that have been used in support of the two main forms of exclusivist assertion, namely that the founder of their Faith is unique and eternally supreme and that each Faith provides its followers with the sole means of salvation. In this article, an approach from a Bahá'í perspective is offered to the resolution of conflicts arising from such claims in Christianity. It is our submission that the Bahá'í approach outlines models for resolving similarly divergent claims.

\section{Texts and Interpretations}

Traditional Christian doctrine presents two sets of scriptural quotations in support of its claims. First, there are those quotations dealing with the idea that Jesus Christ is the unique incarnation of God:

... for God so loved the world that He gave His only begotten Son. (Jn 3:16)

The Word was God ... and the Word was made flesh. (Jn 1:1,14)

Jesus Himself stated, "I and my Father are One (Jn 10:30)

He that seeth me seeth him that sent me. (Jn 12:45)

I am the way, the truth, and the life: no man cometh unto the Father, but by me. (Jn 14:6)

Equally, many biblical passages support the second category of exclusivist assertions, namely that Jesus Christ provides the exclusive route to salvation and that therefore salvation is an exclusively Christian preserve. The latter set of quotations are categorized by Christian doctrine as being soteriological, as distinct from the ontological passages, which confer uniqueness to the person of Jesus Christ.

For there is none other name under heaven given among men, whereby we must he saved. (Acts 4:12)

He that believeth and is baptized shall be saved, he that believeth not shall he damned. (Mk 16:16)

1. For an explanation of these terms, see Barrett, World Christian Encyclopedia 71.

2. See, for instance, Second Vatican Council's (1965) Declaration on the Relationship of the Church to Non-Christian Religions. However, some commentators believe that even the ecumenical attitude to other religions is short lived. For instance, a 1989 article states, "The new Pope (John Paul II) was not interested in accommodation with the world, but in reaffirming the Church's Catholic identity on the way to reconquering it" (The Economist, "Lonely" 20). 
For there is one God, and one Mediator between God and men, the man Christ Jesus. (1 Tm 2:5)

Christian exclusivity was later summarized in the traditional Roman Catholic doctrine, which stated that outside the Church there is no salvation, and in its Protestant missionary equivalent, that outside Christianity there is no salvation. Further, one of the Articles of Faith of the Church of England states, "For holy Scripture doth set out unto us only the Name of Jesus Christ, whereby men must be saved” (Book of Common Prayer 619). The Evangelical Alliance puts it more bluntly, "Those who receive Christ are saved; those who reject him are lost" (Christianity 23).

Our assertion is that these beliefs are not consistent with a reasonable Christian faith. Is it credible that the loving God and Father of all people, "the true light which lighteth every man” (Jn 1:9), who desires "all men to be saved” (1 Tm 2:4), who "love(s) them that love me" (Prv 8:17), who "accepted" those who "worketh righteousness" (Acts 10:35), has decreed that only those born within one particular thread of human history shall be saved? The manifest injustice of an exclusive access to salvation has even been apparent to the church for some time. An example of this conceptual problem is evident in the statement from the Chicago Congress on World Mission, intended as an incitement to missionary activity, as far back as 1960: "Since the War (World War II) more than one billion souls have passed into eternity and more than half of these went to the torment of hell fire without even hearing of Jesus Christ, who he was, or why he died on the cross of Calvary” (quoted in Hick, Second 77).

Conversely, the Bahá'í approach stresses the unity of all religions and the need to eradicate all sources of prejudice. In The Book of Certitude, Bahá'u'lláh explains the rank and station of the Manifestation of God. In essence, this involves the recognition of both a human and a divine nature in each of the Manifestations. In each of these stations, a different type of language is used by the Manifestation of God. The utterances of their divine station-the first station-involve the use of "the attributes of Godhead, Divinity, Supreme Singleness, and Inmost Essence ...” (Gleanings 53). This station is also called the station of "essential unity" (Gleanings 51). Here, all the Manifestations "abide in the same tabernacle, soar in the same heaven, are seated upon the same throne, utter the same speech, and proclaim the same Faith" (quoted in Shoghi Effendi, The World Order 58). The second station is characterized by distinction between the Manifestations, “... temporal limitations ... they manifest absolute servitude, utter destitution, and complete self-effacement” (Gleanings 53-54). Their language in this station, therefore, reflects this distinction. These two stations are summarized later by Bahá'u'lláh: "Were any of the all-embracing Manifestations of God to declare: 'I am God,' He, verily, speaketh the truth. ... And were they to say, 'We are the Servants of God', this also is a manifest and indisputable fact” (Gleanings 54).

And since there can be no tie of direct intercourse to bind the one true God with His creation, and no resemblance whatever can exist between the transient and the 
Eternal, the contingent and the Absolute, He hath ordained that in every age and dispensation a pure and stainless Soul be made manifest in the kingdoms of earth and heaven. Unto this subtle, this mysterious and ethereal Being He hath assigned a twofold nature; the physical, pertaining to the world of mailer, and the spiritual, which is born of the substance of God Himself. He hath, moreover, conferred upon Him a double station. (Bahá'u’lláh, Gleanings 66)

There is much evidence in the Gospels that can be viewed as supporting this perspective. During an interview with a group of Roman Catholic bishops in Paris in 1913, 'Abdu'l-Bahá provides an example of this approach when he was asked, "Who is Jesus Christ and what was the nature of His Being?" In response, 'Abdu'l-Bahá said Christ "was as is stated in the Gospels, but we explain their meanings”3 (Khitábát 737). This invites us to investigate what the scriptures teach and what their explanations are.

The Gospels can indeed be seen to provide two opposite aspects to Christ's personality: his humanity and his divinity. Previously quoted passages indicate Christ's divinity. The following verses are expressions of his humanity:

Jesus cried and said, He that believeth on me, believeth not on me, but on him who sent me. (Jn 12:44)

And a certain ruler asked him, saying, Good Master, what shall I do to inherit eternal life? And Jesus said unto him, Why callest thou me good? none is good, save one, that is, God. (Lk 18:18)

For I came down from heaven, not to do mine own will, but the will of him that sent me. (In 6:36)

My Father is greater than I. (Jn 14:28) ${ }^{4}$

Jesus, faithful to the One appointing him, ${ }^{5}$ just as Moses also was. (Heb 3:2)

But of that day (the Day of Judgment) and that hour knoweth no one, not even the angels which are in heaven, neither the Son, but the Father. (Mk 13:32)

The last of these Gospel verses clearly does not equate the knowledge of Jesus "the Son" and that of God "the Father." In summary, the two aspects of Christ's relationship with God are reconciled and may be understood by Bahá'u'lláh's explanation of the station of the Manifestation of God. In a simplified manner, it is possible to say that this perspective identifies Christ as God, but not God as Christ. The Manifestation is a reflection of God's attributes, and therefore all humanity can know of God, but the Manifestation is not the incarnation of God's essence. The late Bishop John Robinson uses the term "expression"6 in his explanation of Christ's station, "He was the complete expression, the Word of God. Through him, as through no one else, God spoke and God acted; when one met him, one was met and saved and judged by God" (Honest 71). This insight is reiterated in Professor Dodd's brilliant study of the Fourth Gospel

3. Author's translation from the original Persian authorized by Ad Hoc Committee on Translations, Bahá'í World Centre.

4. Compare with "I and my Father are One" (Jn 10:30).

5. Literally "making him."

6. See Heb 1:3, which refers to Christ as the "express image" of the Father. 
where he explains that the relationship described in the words "I am in the Father and the Father in me" (Jn 10:38) "is conceived as a dynamic and not a static relation; it consists in an activity originating with the Father and manifested in the Son” (Interpretation 194).

In addition, the literal interpretation of exclusive statements has been questioned by several Christian thinkers. Their objections have been based on an awareness of the type of language used in the Gospels. The first of these has been discussed, among others, by John Hick. He observes that the writing of many of the Gospel writers appropriately expresses loving devotion and commitment, "of spiritual reflection rather than reliable history” (Carpenter, Jesus 14). Hick concludes that the treatment of many Gospel passages as literal propositions misrepresents their purpose and meaning. To call Jesus "God," "Son of God," or "God incarnate" is to use "poetic" or "mythological” language (Hick, Jesus 175; God 172). He gives this analogy: "That Jesus is my Lord and saviour is language like that of the lover for whom Helen is the sweetest girl in the world. Logically, there can only be one sweetest girl in the world; but if we treat the lover's words literally and infer from them the claim that every girl is less sweet than Helen, we shall not be doing justice to the kind of language he is using” (Hick, Second 32). Likewise, if the confession of Jesus as Lord and Savior is taken to mean that humankind cannot respond to God except through Jesus, "we misuse the language of personal commitment and turn living religion into dogmatic exclusiveness" (Hick, Second 32).

\section{Allegorical Language}

The second basis of Christian objection to literal interpretation derives from an understanding of the allegorical language used in the Bible. Jesus used thirty-nine parables to explain spiritual meaning. Of them, He says, "I speak to them in parables, because they seeing see not, and hearing hear not, neither do they understand" (Mt 13:12-13). Barr interprets the incident of the temptation of Jesus by the devil in the following way:

The narratives as we have them in Matthew and Luke are two attempts to express the inexpressible in human terms ... the stories are something like a legend. They are not factual reporting of conversations that acoustically took place. The encounter of Jesus with the devil was real, and so the story relates to a real event of some kind: but the description which it gives of it is a legendary one, such as to give us a sufficient and adequate impression of its meaning. (Escaping 79-80)

The expression of the "inexpressible" to which Barr refers is precisely the purpose of metaphor. In using metaphor, however, it is necessary to examine the two components that are being compared and to look for qualities in common. In this context, the qualities are not physical but spiritual. In saying that $\mathrm{He}$ is, for example, the "bread of life" (Jn 6:48), Jesus is obviously not referring to the literal interpretation but to the common spiritual qualities that such a metaphor suggests. That He is essential, vital, abundant, and a source of spiritual nourishment is clearly a more reasonable interpretation (Hatcher, Purpose 90-91). 
Dodd points out that the synoptic parables should not be confused with the even richer symbolism of the Fourth Gospel (Interpretation 134). The explicit use of symbols in this Gospel such as bread of life, living water, the true vine, and the good shepherd, is different from the narratives and other parables of earlier Gospels. A parable is a real life story, presenting a situation that the hearers will recognize. From this story they will be able to infer a moral or spiritual significance. Symbolism, however, presupposes knowledge of the realities for which the symbols stand and derives its significance from a background of thought in which these had already served as symbols for religious conceptions. In this context the Fourth Gospel writer's acquaintance with the Platonic Doctrine of Ideas is probably relevant. This conception of a world of invisible realities of which the visible world is a copy clearly "had entered into the texture of thought" (Dodd, Interpretation 139). In this light the use of symbolism in describing the nature of Jesus can be understood. For example, Jesus says "I am a good shepherd" (Jn 10:11). "What makes a shepherd a shepherd? The fact that he realizes in himself the eternal idea of shepherdhood, which is manifested in Christ" (Interpretation 140).

The relevance of the Platonic influence can be clearly seen in the light of a passage in Paul's epistle to the Colossians. Christ here is described as the One "Who is Image of the Invisible God" (Col 1:15). The Greek word used for image is eikon, the very same word Plato used to describe the reflection of the sun in the water. "Paul's teaching to the Colossians was that there was not a mere coincidental resemblance between Jesus Christ and His Father (homoioma), but they were eternally related One to the Other (eikon). The One was a reflection of the Other who was real and not merely the figment of thought or imagination” (Study Bible 1456). This perspective correlates with the analogy often used in Bahá'í writings to explain the relationship of the Manifestation to God. The analogy is that of a mirror reflecting sunlight. As Sabet explains, "If we compare Divinity with the sun, the messenger is like a pure and perfect mirror in which the sun is reflected. Now, the mirror in referring to the sun might say of itself: 'The sun is in me', or 'I am a reflector of the sun', or 'I am a fragile mirror" (Sabet, Heavens 102).

Thus the "veiled and concealed" (Book of Certitude 255) language of revelation can be understood in light of these hermeneutic insights: "These things we also speak. ... they are spiritually discerned" (1 Cor 2: 13-14). Similarly, Jesus' identity with God can be seen as a divine metaphor. Because Jesus is not physically similar to the Almighty, the Bahá'í perspective is that He is the incarnation of names and attributes rather than an incarnation of the essence of God. $^{7}$

\section{Relativity and Religious Truth}

The final approach that could be considered is the relativity of religious truth conveyed by scripture. The fundamental principle enunciated by Bahá'u'lláh is

7. Bahá'í writings point out that God "can in no wise incarnate His infinite, His unknowable, His incorruptible and all-embracing Reality in the concrete and limited frame of a mortal being” (Shoghi Effendi, The World Order 112). 
that "religious truth is not absolute but relative ..." (Shoghi Effendi, Promised Day v); it is relative (as shown by the use of metaphor and parable in the Gospels) to the kind of literature it is, to the kind of event being narrated, to the kind of theological use to which the statement is being put, and to the theological importance of the realities to which the statement refers. An important aspect of this principle is the relativity of the revelation of the Manifestation to the age in which He lived. Both in referring to the past and the future, this principle is propounded in the Bible. Of the past, God "at sundry times and in divers manners spake in times past unto the fathers by the prophets" (Heb 1:1). The criterion for belief in Jesus is belief in Moses: "Had ye believed in Moses, ye would have believed Me" (Jn 5:44). And of the future, the writer of Acts of the Apostles states that "the times of refreshing shall come from the presence of the Lord, ... the times of the restitution of all things" (Acts 3:19, 21). Accordingly, Jesus stated that "I have yet many things to say unto you, but you cannot bear them now" (Jn 16:12), and Paul explains that "I have fed you with milk, and not with meat: for hitherto ye were not able to bear it, neither yet now are ye able" (1 Cor 3:2). Here the distinction between Jesus (the individual Manifestation of God for his age) and the Christ (the Word of God, the divine Logos which "lighteth every man that cometh into the world" [Jn 1:9] and is the "same yesterday, today, and forever" [Heb 13:8]) is critical to the understanding of the progressiveness of divine revelation.

The assertion of uniqueness is not exclusive to Christianity; indeed elsewhere in the Bible repeated mention is made of the uniqueness of Moses, the High Prophet of Judaism. The Bible teaches that "unto his brother Aaron" (who was a prophet in his own right), Moses was "instead of God" (Ex 4:16). He is the only individual in human history "whom the Lord knew face to face" (Dt 34:10), and with whom the Lord spoke "mouth to mouth" (Nm 12:8). In addition to Moses' personal uniqueness, the Laws and statutes He established were intended to be "for ever," to be followed "throughout their generations" (Ex 27:2 1, 28:43; Lv $6: 18,6: 22,7: 34,10: 9,10: 15,16: 31,17: 7,18: 33,23: 14)$. The salvation offered to the people of Israel was to be permanent and abiding. The God of Israel announced to them that "beside me there is no saviour" (Is 43:11) and that "this salvation shall be forever" (Is 51:6). If the same tools of literal interpretation were used for these quotations of the Old Testament to show Jewish exclusivity, as have been used for the New Testament to demonstrate the absoluteness of Christianity, Christians would have difficulty in demonstrating the fulfillment of the Jewish religion in Christianity. ${ }^{8}$

8. Maimonides demonstrates this problem in the case of the Laws of the Jewish religion: "You must not imagine that the Messiah must prove his Messianity by signs and miracles, doing something unexpected, bringing the dead to life, or similar things, etc. The principal thing is this: the statutes and precepts of our Torah remain for ever, and nothing can be added to them nor ought taken from them. If, therefore, a descendant of David earnestly studies the law, observes, like David his father, what the Law, both written and oral, enjoins, causes all Israelites to act similarly, exhorts those who are lax in the performance of the commandments, and fights the wars of the Lord: he may possibly be Messiah” (quoted in Friedlander, Jewish 226-27). 
In conclusion, we have attempted to show that the sublimity and unique importance of Jesus Christ resides in his station of divinity. However, this is no basis for exclusivity because in their divine station all the Manifestations of God are exponents of one unity. The Bahá'í principle of progressive revelation argues against the attribution of uniqueness to any single founder-prophet and instead accords a unified exclusivity to all the Manifestations of God. 'The contribution of this insight to interreligious dialogue may facilitate the process of reconciling theological differences among the major world religions "in a great spirit of mutual forbearance that will enable them to work together for the advancement of human understanding and peace” (Universal House of Justice, Peoples 13).

\section{Works Cited}

'Abdu’l-Bahá. Majmú 'Ah-yi Khitábát Hadrat 'Abdu’1-Bahá [Khitábát: Talks of ‘Abdu’l-Bahá]. Rev. ed. Hofheim-Langenheim: Bahá'í-Verlag, 1984.

Bahá'u'lláh. Gleanings from the Writings of Bahá'u'lláh. 2d. ed. Trans. Shoghi Effendi. Wilmette: Bahá'í Publishing Trust, 1976.

—. The Book of Certitude. 3d. ed. Trans. Shoghi Effendi. Wilmette: Bahá'í Publishing Trust, 1976.

Barr, J. Escaping from Fundamentalism. London: Student Christian Movement, 1988.

Barrett, Donald. World Christian Encyclopedia. New York: Oxford University Press, 1982.

Beckwith, F. Bahá'í-A Christian Response to Baha'ism, The Religion Which Aims toward One World Government and One Common Faith. Minneapolis: Bethany House Publishers, 1985.

Book of Common Prayer and Administration of the Sacraments, The. Cambridge: Cambridge University Press, 1962.

Boykin, J. The Bahá 'í Faith. Grand Rapids: Inter-Varsity Press, 1982.

Carpenter, H. Jesus. Oxford: Oxford University Press, 1980.

Dodd, C.H. The Interpretation of the Fourth Gospel. Cambridge: Cambridge University Press, 1968.

Evangelical Alliance, The. Christianity and Other Faiths. Exeter: Paternoster Press, 1983.

Friedlander, M. The Jewish Religion. 8th ed. London: Shapiro, Valentine and Co., 1953.

Hatcher, J. The Purpose of Physical Reality. Wilmette: Bahá'í Publishing Trust, 1987.

Hebrew-Greek Key Study Bible, The. Ed. Spiros Zodhiates. Chattanooga, TN: AMG Publishers, n.d.

Hick, J. God and the Universe of Faiths. London: Macmillan Press, 1988.

. "Jesus and the World Religions" in The Myth of God Incarnate. Ed. John

Hick. London: Strident Christian Movement Press, 1977.

. "The Non-Absoluteness of Christianity” in The Myth of Christian 
Uniqueness. Ed. John Hick and Paul Knitter. London: Student Christian Movement Press, 1987.

- The Second Christianity. London: Student Christian Movement Press, 1982.

Johnson, P. The History of Christianity. London: Pelican Books, 1976.

Küng, H. Christianity and the World Religions. London: Collins Publishers, 1985.

“Lonely Eminence, A.” The Economist. 313 (7632): 19-23, December 9, 1989.

McCormick, J. The History and Doctrine of the Bahá'í Faith. Belfast: Great Joy Publications, n.d.

Robinson, J. Honest to God. London: Student Christian Movement Press, 1963.

Ruether, R.R. "Feminism and Jewish-Christian Dialogue" in The Myth of Christian Uniqueness. Ed. John Hick and Paul Knitter. London: Student Christian Movement Press, 1987.

Sabet, H. The Heavens are Cleft Asunder. Oxford: George Ronald, 1975.

Shoghi Effendi. The Promised Day Is Come. Rev. ed. Wilmette: Bahá'í Publishing Trust, 1980.

. The World Order of Bahá'u'lláh. 2d ed. Wilmette: Bahá'í Publishing Trust, 1974.

“Still Islam, not Waslam.” The Economist. 310 (7589): 15-16, February 11, 1990.

Universal House of Justice, The. "To the Peoples of the World.” Bahá'í Studies. Vol. 14. Ottawa: Association for Bahá'í Studies, 1986. 